\title{
Progressive supranuclear palsy motor phenotype in a patient with pineocytoma
}

\section{Figure $\quad$ MRI of the pineal lesion}
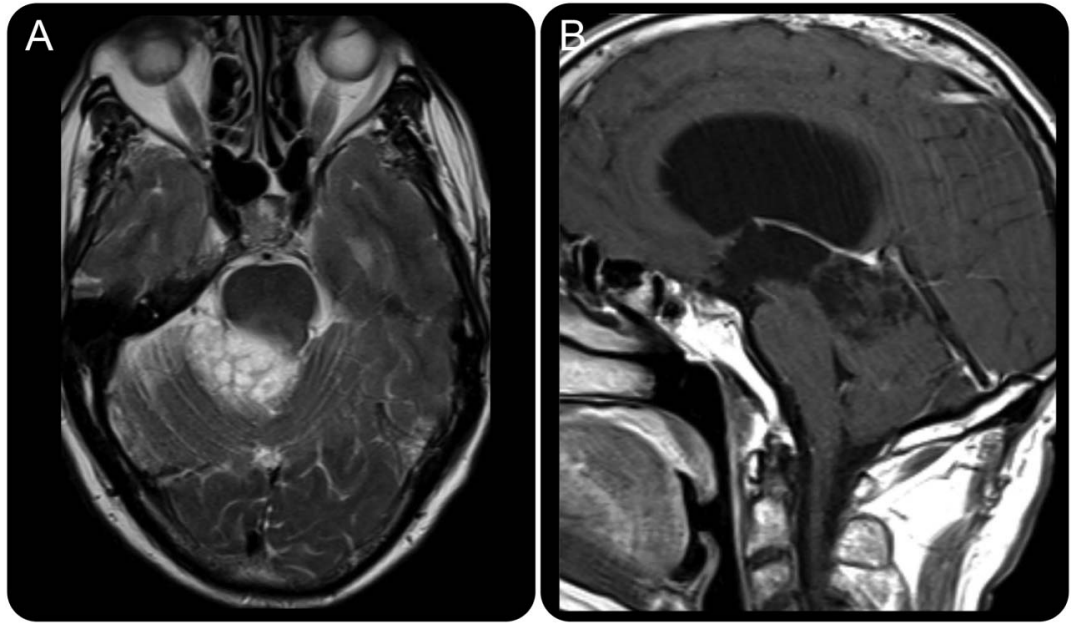

(A) Axial T2-weighted image demonstrates an extra-axial right paramedian mass of the pineal region, with a "bubbly" aspect, with midbrain distortion and aqueduct compression. (B) Sagittal, contrast-enhanced, T1-weighted image shows no enhancement, in keeping with a nonaggressive behavior.

A 76-year-old man developed gait disorder with falls over the course of 2 years. On neurologic examination, he had apraxia of eyelid opening, vertical supranuclear gaze palsy, dysarthria, and dysphagia. There was facial hypomimia, moderate axial rigidity, symmetrical bradykinesia, and no tremor. Gait was characterized by freezing and postural instability. Cognitive assessment was normal. Brain MRI revealed a multiloculated lesion of the pineal region causing midbrain (tectal plate) distortion (figure). Histology was compatible with pineocytoma. Descriptions of clinical pictures resembling progressive supranuclear palsy caused by midbrain tumors are historical, ${ }^{1}$ especially by a rare tumor in adulthood.

Joana Martins, MD, Sérgio Moreira, MD, Ângelo Carneiro, MD, Nuno Vila-Chä, MD

From the Departments of Neurology (J.M., N.V.-C.), Neurosurgery (S.M.), and Neuroradiology (A.C.), Centro Hospitalar do Porto, Portugal.

Author contributions: Joana Martins: study concept and design, acquisition, analysis, and interpretation of data. Sérgio Moreira: acquisition, analysis, and interpretation of data. Ângelo Carneiro: acquisition, analysis, and interpretation of data. Nuno Vila-Chã: study concept and design, analysis and interpretation of data, critical revision of manuscript.

Study funding: No targeted funding reported.

Disclosure: The authors report no disclosures relevant to the manuscript. Go to Neurology.org for full disclosures.

Correspondence to Dr. Martins: jcsfmartins@gmail.com

1. Siderowf AD, Galetta SL, Hurtig HI, Liu GT. Posey and Spiller and progressive supranuclear palsy: an incorrect attribution. Mov Disord 1998;13:170-174. 


\section{Neurology}

\section{Progressive supranuclear palsy motor phenotype in a patient with pineocytoma Joana Martins, Sérgio Moreira, Ângelo Carneiro, et al.}

Neurology 2016;87;340

DOI 10.1212/WNL.0000000000002870

\section{This information is current as of July 18, 2016}

\author{
Updated Information \& \\ Services
}

References

Subspecialty Collections

Permissions \& Licensing

Reprints including high resolution figures, can be found at: http://n.neurology.org/content/87/3/340.full

This article cites 1 articles, 0 of which you can access for free at: http://n.neurology.org/content/87/3/340.full\#ref-list-1

This article, along with others on similar topics, appears in the following collection(s):

Primary brain tumor

http://n.neurology.org/cgi/collection/primary_brain_tumor Progressive supranuclear palsy

http://n.neurology.org/cgi/collection/progressive_supranuclear_palsy

Information about reproducing this article in parts (figures,tables) or in its entirety can be found online at:

http://www.neurology.org/about/about_the_journal\#permissions

Information about ordering reprints can be found online:

http://n.neurology.org/subscribers/advertise

Neurology ${ }^{\circledR}$ is the official journal of the American Academy of Neurology. Published continuously since 1951, it is now a weekly with 48 issues per year. Copyright (O 2016 American Academy of Neurology. All rights reserved. Print ISSN: 0028-3878. Online ISSN: 1526-632X.

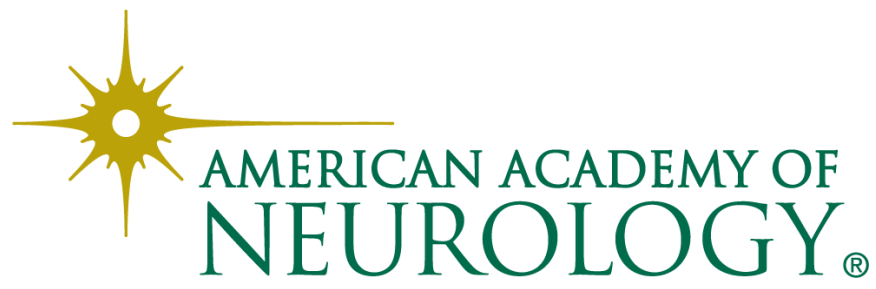

